University of Wollongong

Research Online

Faculty of Social Sciences - Papers (Archive) Faculty of Arts, Social Sciences \& Humanities

2015

Filling up silences-first in family students, capital and university talk in the home

Sarah Elizabeth O'Shea

University of Wollongong, sarah.oshea@curtin.edu.au

Follow this and additional works at: https://ro.uow.edu.au/sspapers

Part of the Education Commons, and the Social and Behavioral Sciences Commons

Research Online is the open access institutional repository for the University of Wollongong. For further information contact the UOW Library: research-pubs@uow.edu.au 


\title{
Filling up silences-first in family students, capital and university talk in the home
}

\begin{abstract}
Internationally, research has indicated that returning to education for older learners provides the means for growth and change, for some students this can translate into a sense of 'empowerment' and control in their personal lives. However, what is not so well researched is how having a significant 'other' present within the university landscape impacts the household and other family members. Exploring how this return to education influences others provides a basis for institutional approaches to engaging with and supporting the lifelong learning of family members, ultimately assisting in the access and participation of current and future generations. This article draws on research conducted with first in family students to explore how their participation in the higher education environment led to conversations in the family around learning. Drawing upon theories of social and cultural capital, this article reflects upon the flow of capitals between home and university.
\end{abstract}

\section{Keywords}

talk, home, silences, family, students, first, up, capital, filling, university

Disciplines

Education | Social and Behavioral Sciences

Publication Details

O'Shea, S. (2015). Filling up silences-first in family students, capital and university talk in the home. International Journal of Lifelong Education, 34 (2), 1-17. 


\title{
Filling up silences -first in family students, capital and university talk in the home.
}

\author{
Dr Sarah O’Shea ${ }^{1}$ \\ Faculty of Social Sciences \\ University of Wollongong \\ Australia \\ $\mathrm{T}+61(2)$ 4221-5838 \\ E: saraho@uow.edu.au
}

Acknowledgement: This work was supported by the University of Wollongong's Educational Strategies Development Fund (2013).

${ }^{1}$ Corresponding author email: saraho@uow.edu.au 


\begin{abstract}
Internationally, research has indicated that returning to education for older learners provides the means for growth and change, for some students this can translate into a sense of 'empowerment' and control in their personal lives. However, what is not so well researched is how having a significant 'other' present within the university landscape impacts the household and other family members. Exploring how this return to education influences others provides a basis for institutional approaches to engaging with and supporting the lifelong learning of family members, ultimately assisting in the access and participation of current and future generations. This article draws on research conducted with first in family students to explore how their participation in the higher education environment led to conversations in the family around learning. Drawing upon theories of social and cultural capital, this article reflects upon the flow of capitals between home and university.
\end{abstract}

Keywords: Higher education participation; cultural and social capitals; intergenerational educational mobility; first in family students

\title{
Introduction
}

According to the latest published figures from the OECD (2013), more than twenty three million students from across the world commenced a university degree in 2013, a student population both numerous and diverse. The increases in university student numbers has been particularly noted in the last twenty years, for example between 1995 and 2011 new enrolments have increased by an average of 20\% across OECD countries from $39 \%$ to $60 \%$, with noticeable growth in the number of entrants who are older and returning to education after a gap in learning. This is a trend that is particularly marked in Australia, for example in the decade between 1994 and 2004, the total number of commencing university students in Australia grew by $36 \%$, but the numbers of students who were school leavers (19 or younger) dropped from 54\% to 50\% (Krause, Hartley, James \& McInnis, 2005). More recently, the OECD (2013) indicates the Australian university population is comparably older than many other OECD member countries. The Australian Bureau of Statistics also report that while three in five (59\%) undergraduate students are aged between 15 and 24 years, a significant $40 \%$ of students are aged between 25 and 64 years, with $1 \%$ being over 64 years old (ABS, 2012).

The global growth in student numbers is partially reflective of the participation targets that have been established in a number of countries across the world, including Germany, Sweden, Ireland, Finland and the United Kingdom amongst other countries (Bradley, Noonan, Nugent \& Scales, 2008). Most of these participation benchmarks recognise the need to attract and engage older students as well as recent school leavers. Based on the Review of Australian Higher Education, led by Denise Bradley (Department of Education, Employment and Workplace Relations [DEEWR], 2008), the previous Australian government committed to increasing the participation of older students in university, with the objective of having $40 \%$ of all 25 to 34-year-olds attaining a qualification at bachelor level or above by 2025. This attainment target is likely to be reached prior to 2025 (Kemp \& Norton, 2014), assisted by the introduction of the demand driven system in 2012. This new open system of enrolment has removed existing caps on student places, enabling individual institutions to nominate the number of places in all disciplines, excepting medicine. 
The recent Kemp and Norton (2014) review of this system has recommended that while the participation of students from diverse backgrounds should be encouraged, participation goals should be abolished and replaced solely by this competitive uncapped educational market. Regardless of whether participation targets are removed, the university student population continues to expand and given the predicted decline in school leavers over the next 10-15 years, many of these new enrolments will be derived from 'other age groups' (ACER, 2011), including those who are older and first in family. It is thus timely to initiate detailed exploration of how returning to education as an older, first in family learner impacts upon those closest to these students and influences family discourses around learning.

This article presents research conducted with first in family students at an Australian university in 2013. The majority of participants were categorised as mature aged (over 21 years) and only one had entered university directly after school. The study was relatively small $(n=25)$ but generated in-depth qualitative data on the motivations of these students and also, how this decision to come to university influenced themselves and others. This article will specifically focus on how social and cultural capitals were used by first in family students in their transition to university and also, the flows of capital between the university and the home. In order to do justice to the subjective nature of this data, a narrative inquiry approach was adopted, which encouraged participants to story their experiences of university. The article presents student stories from two participants, one male and one female. These co-constructed narratives, present my voice alongside the participants in recognition of how 'it is impossible (or if not impossible, then deliberately self-deceptive) as researcher to stay silent or to present a kind of perfect, idealized, inquiring, moralizing self'. (Clandinin \& Connelly, 2000, pp. 61-62)

Beginning with an overview of the current research related to first in family students and university participation, the article will then detail the theoretical framework which extends upon the work of Pierre Bourdieu (1977, 1986, 1990). Following the presentation of the two student narratives, a discussion around the implications of these findings and some possible recommendations for practice will be outlined.

\section{Universities and first in family students: What does being a first in family student mean?}

The research outlined in this article took place in an Australian regional university during 2013; the university has one main campus, with an on-campus student population of 24,000 and a number of smaller satellite campuses located in nearby remote and rural areas, the furthest being $500 \mathrm{~km}$ from the main campus. The university is actively working towards meeting participation goals for student equity groups including those students from low socio-economic (SES) backgrounds; currently $14 \%$ of all students are derived from this category. Like most higher education institutions in Australia, the university is utilising a range of outreach and support activities designed to engage and retain specific student cohorts including Indigenous students, older students and also, those who are accessing university from alternative pathways.

However, university support strategies, whilst commendable, need to actively avoid reproducing neo-liberal discourses where learners are largely constructed as 
'individual customers in an educational market' (Leathwood, 2006, p615). Such assumptions rely upon the agency of the individual thereby ignoring the structural limitations that individuals many have to operate within; the underlying assumption is that everyone is 'unencumbered by domestic responsibilities, poverty or self doubt' (Leathwood, 2006, p615). Students that are first in the family to come to university are regarded as being particularly susceptible to these types of structural constraints. Spiegler and Bednarek (2013) identify this student cohort as being 'more likely to be from lower income and lower status-occupational homes; they tend to be older and they are more likely to belong to an ethnic minority...' (p321).

Not having a significant 'other' in the family or community who can provide 'insider knowledge' about university is regarded as a major obstacle encountered by this cohort. Schools, communities and families all play a key role in building educational capability and social capital (Johnston, Lee, Shah, Shields \& Spinks, 2014; Lareau, 1987; Wilks \&Wilson, 2012). A recent national Australian study (NCVER, 2014) reports that those in more economically disadvantaged communities are 'more likely to leave school early and consequently less likely to attend university or undertake vocational education and training' (Johnston, et al, 2014, p.10). Drawing on the research of Long, Carpenter \& Hayden (1999), Wilks and Wilson (2012) indicate that the educational aspirations of young people reflect '...the influence of parents and siblings (cultural capital) and the local environment (social capital) especially in the last two years of primary and the first two years of secondary school' (p83). A number of studies conclude that individuals, particularly young people, who do not have access to an individual or institution that can assists in nurturing an educational 'future', may not consider university and instead conceive of this as outside their range of possibilities (Gorard, Rees, Fevre \& Furlong, 1998; Harrell \& Forney, 2003; Thayer, 2000; Tramonte \& Willms, 2009 amongst others)

The research literature on educational participation also makes clear links between parents' attitudes and experiences of education in relation to children's educational trajectories and success. Gorard, Rees, Fevre and Welland (2001) report that parental attitudes about learning are significant influences on perceptions and ambitions around educational achievement for family members. A number of studies have also argued that the level of parental education is a key influence on children's academic success (Feinstein, Duckworth \& Sabates, 2004; Grayson, 2011; Knighton, 2002). While Feinstein et al (2004) and Grayson (2011) are referring to school education, Knighton (2002) underlines the impacts of parents educational trajectories on higher education access, stating: 'Parental educational attainment has remained a strong and persistent factor relating to post-secondary access' (p18). This is echoed by a recent report by the Australian Institute of Health and Welfare (AIHW, 2014) which draws upon the work of McMillan (2005) and Marks (2007) to highlight how parental educational achievement has had a statistical significant relationship to students' attrition and completion ratios within Australian higher education systems.

Spiegler and Bednarek (2013) have completed one of the most recent reviews of literature and research on first in family students. Based on a review of 70 studies conducted in the last two decades and derived mainly from the USA, Germany, UK and Canada, these authors report how this student cohort often feel 'out of place' in universities, the number of first in family students who work is also proportionally higher than those who are not first in family, this group is also more likely to live off- 
campus which when combined with higher hours of work may preclude or limit involvement with university activities. Aside from these structural constraints there are also, other more covert obstacles that this cohort may encounter.

Ball and Vincent (1998) refer to the concept of 'hot' knowledge derived from social networks that first in family students did not appear to have access to. This hot or grapevine knowledge provides local and contextualised insight into educational institutions and is often regarded as more legitimate than 'cold' or official knowledge sources derived from the institution. Other invisible challenges to first in family students, particularly those who are younger, have included an apparent lack of a 'sense of entitlement' around university attendance, which lowers self-confidence (Thomas \& Quinn, 2007, p77). Further, Christie, Tett, Cree, Hounsell and McCune (2008) explain that while returning to education exacts an emotional return for all participants, the emotionality of this movement is 'most pronounced amongst students with no previous familial experience of higher education, where there is no reservoir of knowledge to draw upon' (p569).

Whilst the research literature points to the problematic nature of university participation for first in family students, it is important that this group is not viewed only in deficit terms. We cannot simplify what is essentially a complex social issue; the reasons for the low educational outcomes for certain learner cohorts are complicated and multifaceted. The foundations for these issues are both structural and social in nature; arguably placing the emphasis on the individual student has the potential to negotiate this as the students' lack rather than the result of structural and ideological forces. Equally, some studies indicate that first in family students are not necessarily lacking. For example, Dumais and Ward's (2010) analysis of the United States' National Education Longitudinal Study (1988) and the Postsecondary Education Transcripts indicated that first in family status was restrictive only in terms of initial entry to university but that this diminished as students proceed through the degree program. There are also other factors that may assist first in family students that earlier research may not have been able to consider. For example, Wohn, Ellison, Khan, Fewins-Bliss \& Gray (2013) shift focus from knowledges and information derived only from family members or educational institutions and instead consider social media as a source of support for this first in family cohort. These authors argue that 'it could be that social media tools have the ability to intensify latent connections that could be useful in animating high school students' college aspirations, facilitating the transfer of information about college, and ultimately enhancing expectations of future college success' (p426).

Clearly, any analysis of first generation participation needs to be approached from a diversity of 'interconnected perspectives' (Thomas \& Quinn, 2007, p64). Despite constraints and apparent educational stratification, first in family students do make it to university and yet relatively little is known about how this cohort manage this university experience, particularly older students. There remain gaps in our understanding of how moving into the higher education environment informs the learning discourses and capital resources of both these students and their families. Of particular interest in this study was the types of 'ripple effects' this change in educational status had for those closest to learners. While this is a small study and is contextualised by location, time and participants, focusing on the repercussions of this attendance on the household and community addresses an underexplored facet of the 
first in family student experience. The following section details the theoretical framework for this study and the research design, before presenting two student narratives. This richly detailed data will be followed by a discussion and some recommendations for practice.

\section{Theoretical framework}

This study draws upon Bourdieu's (1977) theories of social and cultural capitals in exploring how first in family students move into higher education and manage this field. Capitals, field and habitus are regarded as forming the 'conceptual cornerstones' of Bourdieu's theories (Bennett \& Silva, 2011, p429) these economic and noneconomic criteria work together to maintain social status and hierarchies (Bourdieu, 1986). Bourdieu recognises that the social world is more complex than simply being based upon economic wealth, instead certain forms of capital work symbolically to support and maintain hierarchies of power. Both cultural and social capitals are maintained by 'symbolic exchanges' and retain a certain level of taken for grantedness or invisibility within society. For example, cultural capital is largely bestowed via family membership through various embodied, institutionalised and objectified states whereas social capital refers to networks of connections held by people and the entitlements these enable. These networks produce or reproduce inequality and are largely reproductive, ultimately legitimising the positioning of the powerful and dominant classes.

Another tenet of Bourdieu's social theorisation relates to habitus, which he regarded as the ways in which people are disposed to act, react and behave based upon cultural connections and beliefs. Habitus then refers to the norms and practices of social groups or classes (Bourdieu \& Passeron, 1977), this is not to deny individual agency but rather recognise that elements of the self such as beliefs, values, speech and dress are framed and informed by structural factors such as class, gender and ethnicity. An individual's habitus is not fixed or bounded but is instead characterised by unpredictability and arbitrariness. This is summed up by Reay (1998) who describes habitus as '...primarily a dynamic concept, a rich interlacing of past and present, individual and collective interiorized and permeating both body and psyche' (p521). Hence, habitus can be regarded as a 'transforming machine' that while reproducing the dominant social conditions does this in a 'relatively unpredictable way'. (Bourdieu, 1990, p87).

Bourdieu (1986) argued that individuals enter the education system with various capitals and habituses, each contributing to levels of academic success. Cultural and social capitals are not distributed equally; those in the higher status group are argued to have greater access to the valuable forms of capitals compared to those who are identified as being in the lower strata of society. Tramonte and Willms (2009) highlight how families from lower socio-economic backgrounds are generally perceived as having lower levels of cultural capital to draw upon which in turn limits the educational success of the learners in the family. These authors explain that '...low income parents fail to support their children in succeeding in school not because they see too low a payoff to such action, but because they lack the skills, habits, and knowledge needed to effectively assist them' (Tramonte \& Willms, 2009, p201). Whilst Tramonte and Willms (2009) are largely concerned with school education, this conceptualisation of different forms of cultural capital can equally be 
applied to higher education as just like schools, higher education institutions are also: 'places where codes from higher socio-economic status groups are recognized and where the possession of cultural capital is rewarded' (Tramonte \& Willms, 2009, p.202). Equally, a student's habitus may impact upon their skill in understanding and translating the implicit 'rules of the game' they confront within university (Aschaffenburg \& Maas, 1997, p573). As such, there is recognition that students do not necessarily arrive with lack of knowledge but rather that the knowledge or cultural capital that is favoured within their own social situation may not be valued within the higher education environment they find themselves in, or they may not have knowledge of the 'institutional habitus'. The latter term has emerged to refer to 'the impact of a cultural group or social class on an individual's behaviour as it is mediated through an organisation' (Reay, David \& Ball, 2001, para1.3)

Given that first in family students may not have access to the cultural and social capital favoured within higher education environment and the institutional habitus of the university, this study sought to explore how one group of learners drew upon the various, and perhaps competing, capitals in their transition to university and also investigate the ebbs and flows of these capitals between university and the home.

\section{Research design}

This study occurred in 2013 and was funded by a small internal university grant, the study recruited first year students who had self-identified as being first in family on their enrolment form. Based on this enrolment data, just over 1,500 domestic, first year undergraduate students were identified as being the first to come to university and of these, a random selection of 800 students was sent the email invite. A total of 63 responses were received and 25 students actually participated in an interview; unfortunately two interviews were later removed as both participants were undertaking a second degree.

The term first in family is variously defined. Most definitions rely on parental education levels but may differ in terms of this level, for example in the United States, those students whose parents have completed college levels courses are still considered as being first in family. There is also little understanding about how to define first in family status in terms of blended family arrangements or extended family, which also blurs our understanding of this group. For the purposes of this study, first in family was defined as being the first out of immediate family, which comprised siblings, parents, main caregivers, and children to attend university. All the participants were also enrolled in their first degree. There was no assumption made that first in family status equated to lower income levels or specific class affiliations (Spiegler \& Bednarek, 2013), however a number of the participants indicated that they received social security benefits or resided in government housing during interviews.

The majority of participants were women, who numbered seventeen and ranged in ages from 17 to 62 years; of the 6 men, the oldest was 64 years old and the youngest was 22. Across all the participants, eleven were partnered, there were four single parents (all women) and in total, 12 participants had children. All identified as being first in their immediate families to attend university, but three participants had partners who had either previously studied or were currently studying at a university 
level, these interviews were retained as technically each was the first in their family of origin to participate in higher education. All the participants spoke English as a first language and each was enrolled as a domestic undergraduate student.

\section{Data collection and analysis}

The interviews were all conducted at the completion of the first semester of study (June-July), each lasted between 40-50 minutes and were topic based. Each interview covered four key topics as follows: i) initial experiences of university; ii) reactions from family and friends; iii) family perceptions of university and iv) experiences 'being' a university student. The first topic was designed to encourage the participant to reflect on the beginning stages of study and as all the interviews occurred just after the first semester these reflections were not unduly hampered by memory loss. The second and third topics focussed on how this decision to come to university was perceived by friends and family, particularly in terms of how attending higher education was translated or discussed within the family and household. The fourth topic explored how students managed university in relation to other life spheres and the 'milestones' they had encountered to date. Whilst the data collected explored a number of facets of first in family student experience, of particular interest was how university attendance was received by significant others and also, the types of conversations this participation engendered within the household.

The study was informed by a narrative inquiry approach and sought to employ what Polkinghorne (1995) terms as 'narrative analysis', drawing upon the events, actions and happenings described by interviewees as a basis for 'explanatory stories' ( $\mathrm{p} 5$ ). The focus here is on particularity rather than universality. This is an inductive analytical process that commenced with a question around the range and types of conversations about learning that individuals described. This then was the 'bounded system' and the following stories present this data as a 'composition', a retrospective explanation of 'the happening that is the topic of the inquiry' (Polkinghorne, 1995, p19).

Like Mishler (1986), I found that the interviewees responded to questions in storied forms and this process was further assisted by inviting elaboration on points or by exploring areas that were not anticipated by the initial question. Myself as researcher and the participants existed in a relationship and as Stieha (2010) identifies this type of research is strengthened by 'depth rather than its breadth' (p241). In an attempt to do justice to the depth of the material generated, I have chosen to present the findings in storied form. This was a deliberate move to avoid stripping down the participants' stories, which can occur when findings are presented as a series of decontextualised quotes. Whilst providing multiple quotes and foregrounding common themes across the interviews may add greater weight to the findings or arguments, this slicing of the data also removes the rich contextual depth that participants present in the interview context. How each person decides to narrate their story is not 'haphazard' but instead represents a determined selection that responds to context and audience, whether real or imagined (Rosenthal, 1993, p61). Telling stories is also a learning process for the participants (O'Shea, in-press; Stroobants, 2005), as people story their experiences a 'learning “in” and “through” the story’ can occur (Stroobants, 2005, p50).

As researcher, I have configured the two stories that follow in order to display the 'linkage among the data elements as parts of an unfolding temporal development 
culminating in denouement' (Polkinghorne, 1995, p15). The purpose of narrative analysis is a synthesis of data rather than 'separation of it into its constituent parts' (p15) and the stories that follow have been chosen to provide perspectives from different genders, ages and backgrounds.

\section{Findings}

All of the participants' stories provided rich deep insight into this field, but only two stories are reproduced here. These two participants were chosen simply on the basis of gender, age and relational status as collectively they span the demographics of this group. The first story is narrated by Nigel (pseudonym), a 26-year-old single male who entered university on the basis of high school qualifications. The second story is told by Ann (pseudonym) who is 36 years old and married with two sons; Ann entered university with vocational qualifications. Both narrators are in the first year of an undergraduate degree and neither have any immediate family that has previously attended university. The stories will be presented consecutively, these stories are not paradigmatic but rather each represents a unique perspective on the field

\section{Nigel's Story}

Nigel is single, lives at home with his parents and younger brother (14 years); one older brother has moved away from home. Nigel was interviewed in the first semester of his teaching degree, at 26 he had worked in retail since leaving school at 18 and admits that if asked about university after high school, he would have 'screamed and ran out of the room. It was just not an option for me at the time' and continued by explaining: 'I had such a bad attitude and I was going through a lot of things, my results were very poor as well so I needed that break to get everything back to where I wanted it to be'. For Nigel, his decision to attend university at this stage in his life was very much related to his maturity and his life experiences at work as the following narrative explains:

I would have to say just after high school I had a terrible attitude towards education; I was a bit of truanter as well - I didn't go to a good public school, my teachers were barely there so I was allowed to get away with that sort of behaviour. The other students in my school were monsters; it was not a happy place. I was not in a happy place either so my perception of school, the school system, was very negative and it took me a couple of years to come out of that and really come to terms with the fact that I didn't want to just waste away my abilities in retail. Even customers would notice that I was a bit out of place there. I was successful there but they would be like 'Oh, why are you here? You should be doing so much more, this, that, the other'. That was a good confidence-booster. I think I needed that time to actually get that confidence back. The parallel that I would mostly draw would be the attitude towards education. Now I see it as a tool to really succeed in life and go a little bit further and to specialise in something that you're passionate about. Before I saw it as a waste of time, a waste of money and just something that was unattainable so I felt like I wouldn't be able to do it whereas now I feel capable. Those are the two big, dramatic parallels that I would draw from when I was about 18, 19 to now, 26; big difference in attitude. I've gone through a lot of emotional changes and just developing everything myself - I've done a full 360 I think of everything.

When Nigel was at school, university was rarely spoken about in the household; the silences around attending were palpable. Both his parents were employed - his father had worked his way through a large airline company and was an 'aeronautical 
engineer', whilst his mother was a doctor's receptionist. In response to the question 'How was university spoken about when you were at school?' Nigel described how: 'It wasn't spoken about at home; it was just assumed that we would just start working - in the footsteps of my parents I guess. That was their life that they knew about; how could they possibly offer help in a situation that they had never had experience in?' This silence around further education is partially explained as being rooted in his parents' biography, particularly Nigel mother's who initially was very ambivalent about his choice to continue his education:

[My mother] ... came from a very poor family so she felt that she had to work. I think she actually left high school in Year 9 or Year 10 or something and started working immediately just to earn money so she could support herself. She was living on her own; she came from a broken family and she had to support some of her younger siblings as well. There was always that - she was always frightened with education because it is such a big chunk of time taken away from your life that you could be spending working and earning money.

However, Nigel continued by explaining how this situation has changed since he arrived at university:

It's a lot different. My mother's attitude in particular; my father couldn't care less he's happy but, you know, he doesn't really express it. My mother now uses me as an example for my little brother and so it's that extra tool in the house to get him to do something and even with my older brother because we've seen the positive impact it's had on my life and they know the ins and outs. I tell them everything so they can see that it's not the scary, unknown thing anymore, it's known and it's not scary, it's wonderful. It's really changed the dynamics of the household.

While Nigel's story moves from a perception of self without education to one that is clearly with education, this has not been an uncomplicated linear movement. Instead, it is characterised by breaks and junctures but both Nigel and his family have felt the impacts of this movement:

I'm the first in our immediate family to go to university and it has changed the dynamic of the immediate family because where it seemed that no-one would go on to tertiary education to better themselves, it now, especially for my younger brother who sees me as a role model, it now feels that that door has been opened because someone else has gone through it first. I had always asked him 'Do you want to go to university?' if I'd asked him ten years ago he would say 'No. I hate school, I don't want to go on and do university'. Now he's like 'Oh, okay' - he's reconsidering because he's seen what I do at university and how it's different. His perceptions were, as was my whole family, that it was just too hard and that it was unattainable. We're just a blue-collar family but I've worked hard, I've saved enough money to support myself through this. It's just been a very positive experience so that's ricocheted in the family.

\section{Ann's Story}

Ann has commenced a Science Degree, she is married with two sons aged 13 and 17 years. Currently, Ann works in the retail industry and is the second eldest of a family of seven children. Ann described how she regarded attending university as an opportunity to get a better job: 
I attended TAFE [Technical and Further Education], I did a number of courses just to see what I wanted to do within my life because I'm a retail duty manager at the moment and I really am not happy with my job and wanted to better myself because it's a really poor income as well.

Ann did not consider attending university after school, both the birth of her first child immediately after completing high school and also, the family's social status were described as factors that impacted on her decision not to attend university immediately after school:

Since coming out of school I had my first son, I was only 19 when I had him but that was my choice because I wanted to have children first before I had my career. I always would have loved to go to uni and now that I'm having the chance, I'm loving it. I would never have thought that it could have been possible back when I first had my son. Like I said, when you come from a big family, your parents really don't have enough time for you so you don't get the education that you need at home as well. In some low income families, it's something that you're brought up to just get out and go get a job; you're not brought up to go get a higher education and then go get a job so that's basically how you see life.

Ann had never been on a university campus before her orientation day as she had presumed that 'unless you were a student, you weren't allowed to go. I had no idea that you can go in and have lunch or meet up with somebody if you knew somebody in there or go and speak to somebody academically if you were looking at attending uni'. Similar to Nigel, there was an absence of conversation around university both within her family and broader community but since arriving at university, Ann has actively ruptured this silence, engaging her extended family in her new world of learning: 'I've gone and I've told them that it's a great experience especially to better their careers when they want to get further in their career, they've actually taken on board what I've said. I know two of them are looking at maybe attending uni some time in their life. If it wasn't for me, they probably wouldn't have known any better because it's [university] not really offered for low income families and families that are not high achievers. That's basically what we see our family as'. Ann also explained how she has deliberately engaged in conversations about learning and educational possibilities with her eldest son:

The eldest one is Year 11 so it's a really good thing for him to see me at uni and I'm strengthening his thought process as well because he thinks you should just go out of school and get a trade. I said: 'There are so many more things you can do' and he's like: 'Well I don't know what to do'. I've been stretching his mind I suppose in the way that what else he could be possibly doing in life so he's really looking now at even becoming an interpreter, following a career path so he can go and travel there are so many more things you can do with your life; you're not just stuck in this one position.

For Ann, the support she receives from both her immediate and extended family provides an impetus for her to continue in her studies, while she acknowledged that there is little collective knowledge about this undertaking, their support is unequivocal:

I've had a lot of positive feedback from my family; my husband and both my boys are very, very supportive of me going. That doesn't mean that they help out with the housework as much as me telling them to but they're supportive in the way that 'Yes, 
good on you. That's great that you want to better yourself'. My other sisters and my brothers, they're like 'Oh, okay' but I think they don't know what to expect until I get my final results I suppose. They're like 'Oh, that's nice. Good on you for giving it a go'. I always feel that - especially in my family - people are positive because they want to see me achieve something in life. They can see how hard I work and they know that I don't want to be slogging it out in a retail place for the rest of my life. I see that as... when they talk positive about me doing a course, they can see that I actually want to achieve something in life and doing it not just for me but for my family as well.

\section{Discussion}

Narrative is the best way to understand the human experience because it is the way humans understand their own lives. It is the closest to the human experience and hence the least falsifying of that experience... (Richardson, 1990, p65)

Both Nigel and Ann's stories provide versions of their individual journeys to university; neither narratives is transparent both simply offer one version of reality at a particular point in time. Whilst each is unique there are similarities between the two narratives. Both stories speak of university in terms of 'betterment' for self, career and others. There is a clear sense of the before and after in these stories, with both respondents reflecting on initial perceptions of university as not being for 'people like us' the 'us' being variously described as a 'blue-collar family' (Nigel) and 'low income families and families that are not high achievers' (Ann). Reay's (1998) seminal work on the educational choices of working class youth in the UK, highlights how family habitus or 'the deeply ingrained system of perspectives, experiences and predispositions family members share' (p527) plays a key role in decisions around university participation for school leavers, particularly those who are first in family. Ann and Nigel did not perceive of university as a choice after school but their recent movement into this environment has impacted upon their respective family habitus.

While habitus is initially framed and structured through the family, it does evolve throughout the life course, albeit gradually and can be regarded as constantly changing rather than being static or stable (Thomas, 2002). Ann and Nigel are actively renegotiating the perceptions of others in the family and engaging in dialogue that considers university as a possibility rather than prohibitive, in this way subtle shifts in family habitus seem to be occurring. The stories of these adult learners speak to the reciprocal relationships between the students, their families and the educational institution. Nigel and Ann's stories also inform our understanding about what types of capital are generated by university attendance and how these interact with existing forms of capital, created by family and community networks.

Whilst Ann and Nigel appeared to have had limited access to the institutionalised and objectified cultural capital defined by Bourdieu, this does not signify a lack on their part. Instead, understandings of cultural capital need to be expanded in order to recognise the broader relational wealth that can provide both inspiration and support for first in family students. Nigel reflected on how his status in the family has changed since arriving at university. He is now used as an exemplar for his siblings; the act of stepping into the higher education environment has made the possibility for others to follow his lead a reality. For Ann, it is the emotional support and encouragement of 
her immediate and extended family that provided impetus for her to continue with her studies despite obstacles. Unlike the participants in Waller, Bovill and Pitt's (2011) study, neither Ann nor Nigel had to abandon previous relationships in order to successfully move into the higher education environment instead family relationships provided one form of motivation, a resource that both participants draw upon.

Gofen (2009) argues that first in family students arguably achieve not despite their family backgrounds but rather 'because of' these familial connections. Gofen (2009) identifies how families can be a great source of both emotional and also, embodied support through acknowledgement and encouragement of these educational endeavours. This is another rich source of capital, which is often overlooked or negated; such 'family capital' can provide both motivations and resources required for educational success. Tramonte and Willms (2009) also recognise the multiplicity of cultural capitals, identifying that whilst static forms of cultural capital are negotiated through 'highbrow activities and practices', relational capital is represented by 'cultural interactions and communication' between family members (p200). These forms of capital enable different outcomes; the first represents a family's economic advantage whilst the second provides the necessary skills and knowledge to enable family members to enact success in society, strategically moving forward to obtain goals. This process is undoubtedly assisted by high status and/or economic security but this does not preclude those from a diversity of backgrounds drawing upon existent knowledges in this field. Equally, as both stories attest such capitals flow and ebb between the home and educational domains, each informing the other.

As mentioned previously, Bourdieu largely perceives social capital as a means to replicate social inequality however, if we consider that social capital like habitus is not fixed or static, then it is useful to consider other perspectives of this concept. Social capital is undoubtedly one way that those in power or domination retain this position but Putnam (2000) also perceives of this in terms of a resource that can be used to promote civil engagement and societal health. Whilst Putnam has been criticized for treating social capital as an 'aggregate resource' (Tzanakis, 2013, p11) and there are difficulties associated with measuring the impact of levels of social capital on the broader community, Putnam's differentiation between different forms of social capital namely 'bonding' and 'bridging' social capital can be usefully applied to this data. The first refers to capital that is group-based and more inwardly focused while the second, bridging social capital, is characterized by reciprocity enabling individuals to 'move ahead' (Putnam, 2000, p23). Both Ann and Nigel are actively 'bridging' between the home place and university, Ann explains how she is 'stretching' her son's mind and drawing on her own early experiences as a student to encourage him to consider his future in broader terms. Whilst Nigel provides a source of information about university for his siblings and explains how 'that door has been opened because someone else has gone through it first'. Both take on the role of cultural change agent within the household, actively creating the space for alternative perspectives on educational participation.

However, this movement into higher education arguably also required significant additional work for these participants and for the others in this study. For example, both these stories and others narrated in interviews, reflect an emphasis on the need to 'do' rather than simply 'be', exemplified by the requirement to move from school education into work and/or parenting (in Ann's case). Thomas and Quinn (2007) 
identify how this pervading 'working attitude' is prevalent amongst 'the educational trajectory of first generation entrants' (p86) requiring both reassurance to families 'that they have "invested wisely"' as well as a hidden responsibility to expand 'the aspirations and horizons of the family and its community' (Thomas \& Quinn, 2007, p59). As active agents, Ann and Nigel are expected to move between the institutional habitus of the university and their respective family habituses in an effective and efficient manner. Thomas (2002) advocates a conjoining between the institutional habitus of higher education and that experienced by students within their own social or cultural environments, particularly the 'familial habitus of non-traditional students' (p. 438). Equally, Lawrence (2002) advocates the need for university cultures to change in a 'dynamic' sense encompassing a diversity of 'subcultures'.

In the absence of this 'conjoining', Ann and Nigel demonstrate how they both have worked with other family members, both children and siblings, to shift perceptions of university away from a place which is not for people 'like us' to one that is characterised by accessibility and possibility. Both are actively shifting the nuances of their family habituses, renegotiating these to broaden others' perceptions of educational possibilities and opportunities. In the case of Nigel, this necessitated a rescripting of the past, requiring a shift away from his mother's fear of education, based upon her own experiences of poverty and family responsibilities, to enable his brother to consider university as an option. These types of additional pressures, largely faced by students from diverse backgrounds are often hidden or invisible within higher education institutions, these are the invisible constraints and structures that individuals operate within.

\section{Conclusions}

Pyne and Means (2013) argue that higher education institutions have the possibility of being 'contact zones' (Pratt, 1991), spaces that value 'diverse experiences and ways of knowing and learning' (p187). However, the continuing separation of home and university limits this possibility. Rather than university outreach and support initiatives focusing solely on individual learners, these two stories point to the value of a more holistic approach that includes the family unit. Universities as institutions have to work more actively to dispel the perceptions that these are sacred spaces and instead provide opportunities for parents, children, siblings and partners to engage with the organisation in a meaningful way. Clearly, increasing the 'degree of coupling' (Reay et al., 2001) between the institutional habitus of the university and the individual habitus of first in family students would yield benefit for all parties. Such engagement can both assist future generations to navigate a path to university and complement the resources and capitals that already exist within the household.

Ann and Nigel's stories also indicate the non-linear nature of their educational trajectories, which were interrupted by both work and family commitments. Indeed, an unproblematic forward movement from school to higher education is increasingly no longer the experience for many students (Waller, Bovill \& Pitt, 2011). In order to embrace the diversity of student populations, a more comprehensive understanding of the range of pathways that students take before arriving at university is necessary and recognition of the skills derived from apriori experiences is required. This understanding should be used to inform curriculum content and structure as well as institutional structures such as timetabling. Again, these are the conversations that 
universities need to have with their student body, foregrounding and valuing the narratives of students who have followed this non-linear pathway, can also provide the impetus for others to consider higher education as an entitlement rather than this being viewed as something unattainable.

The conversations and the silences around learning that both Ann and Nigel's stories indicate are relatively unexplored in the research on higher education. In London's (1989) study of first generation students he remarked how he was 'struck by the power students attributed to family voices ... the entreaties, whispers or growls heard at home' (p166). The links between parents' attitudes and experiences of education in relation to children's educational trajectories and success are documented in the literature. Gorard et al (2001) report how family, particularly parents, act as catalysts influencing perceptions and ambitions around educational achievement for family members. However, if there is little understanding of higher education participation amongst family members then conversations about learning may not occur. This silence is not limited to family members; Brooks (2003) also highlights how the young people in her study did not seem to discuss higher education aspirations with peers or friends.

Moving from a state of silence to one of dialogue around educational achievement is significant and transformative. In this study, I was repeatedly struck by the conversations that this student cohort initiated within the home, this transition to university seemed to engender discussions and succeeded in 'filling up silences' that had previously existed. The stories reproduced in this article and told to me during other interviews, provide an understanding of the habitus of the university and that of the family not in terms of demarcations and boundaries but rather as bi-directional flows, ripples of learning that flowed both from and between the institution and the home. With such movement comes the possibility of rupturing of what is expected or anticipated, breaking the silences around university participation provides the means to redefine considerations around educational participation for both current and future generations.

\section{References}

ABS. (2012). Students: Selected Higher Education Statistic. Canberra: Retrieved from http://www.innovation.gov.au/highereducation/HigherEducationStatistics.

ACER. (2011). Student Demand - trends, key markets and the movement towards demand-driven enrolment. [Research Briefing]. Join the Dots Research Briefing 1(1), 1 - 11.

AIHW . (2014). Towards a performance measurement framework for equity in higher education. Cat. No. IHW 129. Canberra: AIHW.

Aschaffenburg, K., \& Mass, I. (1997). Cultural and educational careers: The dynamics of social reproduction. American Sociological Review, 62(4), 573 587.

Ball, S. J., \& Vincent, C. (1998). 'I heard it on the grapevine': 'Hot' knowledge and school choice. British Journal of Sociology of Education, 27(1), 377-400.

Bennett, T., Silva, E. (2011). Introduction: Cultural capital-Histories, limits, prospects. Poetics, 39, 427-443.

Bourdieu, P., \& Passeron, J. C. (1977). Reproduction in Education, Society and Culture. London: Sage Publications.

Bourdieu, P. (1986). The forms of capital. In J. Richardson (Ed.), Handbook of 
Theory and Research for the Sociology of Education (pp. 241 - 257). New York: Greenwood Press.

Bourdieu, P. (1990). Sociology in question. Cambridge: Polity Press.

Bradley, D., Noonan, P., Nugent, H., \& Scales, B. (2008). Review of Australian higher education: final report. Retrieved from http://www.deewr.gov.au/HigherEducation/Review.aspx.

Brooks, R. (2003). Discussing higher education choices: differences and difficulties. Research Papers in Education, 18(3), 237-258.

Christie, H., Tett, L., Cree, V. E., Hounsell, J., \& McCune, V. (2008). 'A real rollercoaster of confidence and emotions': learning to be a university student. Studies in Higher Education, 33, 567-581.

Clandinin, D. J., \& Connelly, F. M. (2000) Narrative inquiry: experience and story in qualitative research. San Francisco: Jossey Bass.

Dumais , S. A., \& Ward, A. (2009). Cultural capital and first-generation college success. Poetics, 38, 245-265.

Feinstein, L., Duckworth, K., \& Sabates, R. (2004) A model of the intergenerational transmission of educational success. Wider benefits of learning. Research Report 10. London: Institute of Education

Gofen, A. (2009). Family capital: How first-generation higher-education students break the intergenerational cycle. Family Relations: Interdisciplinary Journal of Applied Family Studies, 58, 104-120.

Gorard, S., Rees, G., Fevre, R., \& Furlong, J. (1998). Learning trajectories: travelling towards a learning society? International Journal of Lifelong Education, 17, $400-410$

Gorard, S., Rees, G., Fevre, R., \& Welland, T. (2001). Lifelong learning trajectories: some voices of those 'in transit'. International Journal of Lifelong Education, 20(3), 169 - 187.

Grayson, P. (2011). Cultural capital and academic achievement of first generation domestic and international students in Canadian universities. British Educational Research Journal, 37(4), 605-630.

Harrell, P. E., \& Forney, W. S. (2003). Ready or not, here we come: retaining Hispanic and first generation students in postsecondary education. Community College Journal of Research and Practice, 27, 147-156.

Johnston, D., Lee, W., Shah, C., Shields, M., \& Spinks, J. (2014). Are neighbourhood characteristics important in predicting the post-school destinations of young Australians? Adelaide: National Centre for Vocational Education Research.

Kemp, D., \& Norton, A. (2014). Review of the Demand Driven Funding System Report. Canberra: Australian Government.

Krause, K.L., Hartley, R., James, R., \& McInnis, C. (2005). The First Year Experience in Australian universities: Findings from a decade of national studies. Higher Education Innovation Programme: Centre for the Study of Higher Education.

Knighton, T. (2002). Postsecondary participation: the effects of parents' education and household income. Education Quarterly Review, 8(3), 25-32.

Lareau, A. (1987). Social class differences in family-school relationships: the importance of cultural capital. Sociology of Education, 60(2), 73-85.

Lawrence, J. (2002, 8-10 July). The 'deficit-discourse' shift: university teachers and their role in helping first year students persevere and succeed in the new university culture. Paper presented at the 6th Pacific Rim First Year in Higher Education Conference 2002: Changing Agendas - Te Ao Hurihuri, University of 
Canterbury, Christchurch, New Zealand.

Leathwood, C. (2006). Gender, equity and the discourse of the independent learner in higher education. Higher Education (52), 611 - 633.

London, H. B. (1989). Breaking away: A study of first generation college students and their families. American Journal of Education, 97(2), 144-170.

Long, M., Carpenter, P., \& Hayden, M. (1999). Participation in Education and Training 1980 -1994. LSAY Research Report No.13. Melbourne: ACER

Marks, G. (2007). Completing university: Characteristics and outcomes of completing and non-completing students. LSAY Research Report No.51. Melbourne: ACER.

McMillan, J. (2005). Course change and attrition from higher education. LSAY Research Report No.39. Melbourne: ACER.

Mishler, E. G. (1986). Research Interviewing, context and narrative. England: Harvard University Press.

OECD. (2013). How are university students changing? Education Indicators in Focus - 2013/06 (September). (Vol. 15, pp. 1-4). OECD Publishing.

O' Shea, S. (in-press, 2015). Arriving, surviving and succeeding-exploring the first year of university. Journal of College Student Development.

Polkinghorne, D. E. (1995). Narrative configuration in qualitative analysis. International Journal of Qualitative Studies in Education, 8(1), 5-23.

Pratt, M. (1991). Arts of the contact zone. Profession, 91, 33-40.

Putnam, R. D. (2000). Bowling Alone: The collapse and revival of American Community. New York: Simon and Schuster.

Pyne, K., \& Means, D. (2013). Underrepresented and In/visible: A Hispanic firstgeneration student's narratives of college. Journal of Diversity in Higher Education, 6(3), 186-198.

Reay, D. (1998). 'Always knowing' and 'never being sure': familial and institutional habituses and higher education choice. Journal of Educational Policy, 13(4), 519-529.

Reay, D., David, M., \& Ball, S. (2001). Making a difference? Institutional habituses and higher education choice. Sociological Research Online. Retrieved from http://www.socresonline.org.uk/5/4/reay.html

Richardson, L. (1990). Writing strategies: Reaching diverse audiences. Newbury Park, Cal: SAGE Publications.

Rosenthal, G. (1993). Reconstruction of life stories: Principles of selection in generating stories for narrative biographical interviews. In R. Josselson \& A. Lieblich (Eds.), The narrative study of lives (Vol. 1, pp. 59-91). Newbury Park, Cal: SAGE Publications.

Spiegler, T., \& Bednarek, A. (2013). First-generation students: what we ask, what we know and what it means: An international review of the state of research. International Studies in Sociology of Education, 23(4), 318-337.

Stieha, V. (2010). Expectations and experiences: the voice of a first-generation firstyear college student and the question of student persistence. International Journal of Qualitative Studies in Education, 23(2), 237-249.

Stroobants, V. (2005). Stories about learning in narrative biographical research. International Journal of Qualitative Studies in Education, 18:1, 47-61.

Thayer, P. B. (2000). Retention of students from first generation and low-income backgrounds. Opportunity Outlook - Council for Opportunity in Education (May), 2 - 8.

Thomas, L. (2002). Student retention in higher education: the role of institutional habitus. Journal of Educational Policy, 17(4), 423-442. 
Thomas, L., \& Quinn J. (2007). First generation entry into higher education: An international study. Berkshire: Society for Research in Higher Education and Open University Press.

Tramonte, L., \& Willms, J. D. (2009). Cultural capital and its effects on education outcomes. Economics of Education Review, 29, 200 - 213.

Tzanakis, M. (2013). Social capital in Bourdieu's, Coleman's and Putnam's theory: empirical evidence and emergent measurement issues. Educate, 13(2), 2-13.

Waller, R., Bovill, H., and Pitt, B., (2011) Parents, partners and peers: bearing the hidden costs of lifelong learning. International Journal of Lifelong Education. 30(4), 509-526

Wilks, J., \& Wilson, K. (2012). Going on to uni? Access and participation in university for students from backgrounds of disadvantage. Journal of Higher Education Policy and Management 34(1), 79-90.

Wohn, D. Y., Ellison, N. B., Khan, M. L., Fewins-Bliss, R., \& Gray, R. (2013). The role of social media in shaping first-generation high school students' college aspirations: A social capital lens. Computers \& Education, 63(424-436). 